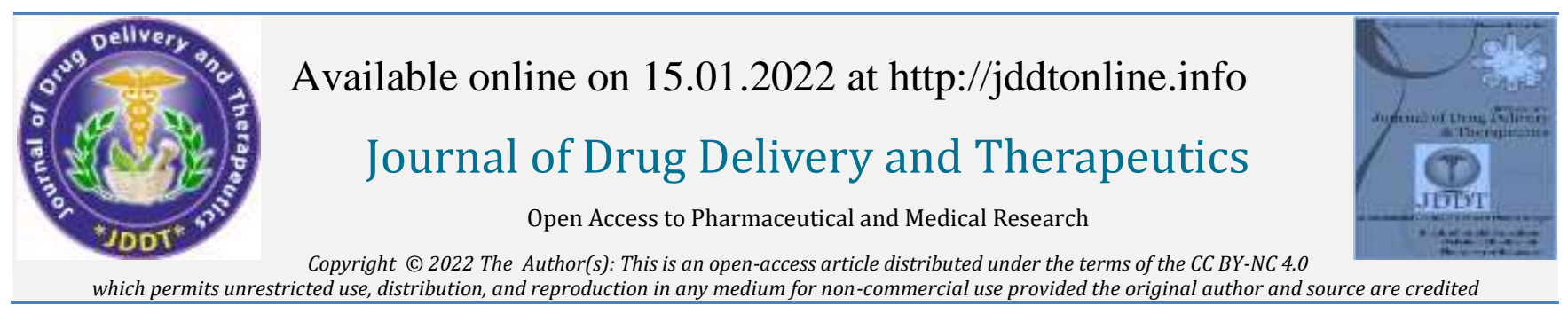

which permits unrestricted use, distribution, and reproduction in any medium for non-commercial use provided the original author and source are credited
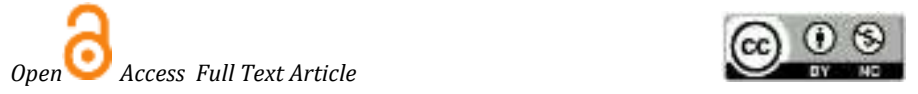

Research Article

\title{
Extraction, Isolation and Standardization of Herbal Species Sida
}

\author{
Karmvir $^{1 *}$, Rakesh Kumar Jat ${ }^{2}$ \\ ${ }^{1}$ Research Scholar, Institute of Pharmacy, Shri Jagdishprasad Jhabarmal Tibrewala University Jhunjhunu Rajasthan, 333001, India \\ ${ }^{2}$ Principal (Professor), Institute of Pharmacy, Shri Jagdishprasad Jhabarmal Tibrewala University Jhunjhunu Rajasthan, 333001, India
}

\section{Article Info:}

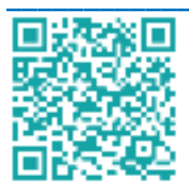

\section{Article History:}

Received 03 November 2021 Reviewed 11 December 2021 Accepted 17 December 2021

Published 15 January 2022

\section{Cite this article as:}

Karmvir, Jat RK, Extraction, Isolation and Standardization of Herbal Species Sida, Journal of Drug Delivery and Therapeutics. 2022; 12(1):62-71

DOI: http://dx.doi.org/10.22270/jddt.v12i1.5175

*Address for Correspondence:

Karmvir, Research Scholar, Institute of Pharmacy, Shri Jagdishprasad Jhabarmal Tibrewala University Jhunjhunu Rajasthan, 333001, India

\section{Abstract}

The main focus of present is study is to find out the various extracts and active constituents from the Sida species which will be very useful in the treatment of many diseases. There are mainly four species (Sida acuta, Sida cardifilia, Sida rhombifolia and Sida spinosa) focused in this research. The aerial part and roots of these species have been collected and authenticated from botany department. The exhaustive solvent extractions have been used based on polarity. The aqueous solvents water, methyl alcohol, ethyl alchol and acetic acids have been used and non-aqueous solvents petroleum ether, ethyl acetate, chloroform, carbon tetra chloride, hexane, heptanes, benzene, toluene have been used for the extraction of active medicaments. The extracts were collected and purified and then tested for pharmacological activities. The extracts or residue are further processed for the isolation of active constituents like vascine, ephedrine etc. These were separated and quantified by high performance thin layer chromatography.

Keywords: Sida acuta, Sida cardifolia, vasicine ephedrine, Extraction, Thin layer chromatography, High performance liquid chromatography.

\section{INTRODUCTION:}

Herbal medicinal drug is extensively practiced in worldwide. for lots of years, humans have become to herbal redress to therapy frequent illnesses like allergy, cold, asthma, bronchitis, compulsive obsessive pulmonary diseases, inflammation. Numerous natural drug treatments are being derived immediately or circuitously from flowers that are viewed as a imperative remedy presently in use for curing a variety of human diseases. The eighty percent of world population using herbal plants as medicine and herbal products for the treatment of different types of disease like rheumatoid arthritis, gout, common cold, snake bite, insect bite, wound healing, skin diseases, ulcerative colitis. Some neuropharmacological disorders like depression, schizophrenia, anxiety, convulsions or epilepsy, insomania, mental illness, Parkinsonism etc are treated many herbal plants. The diseases like diabetes mellitus, asthma, hypertension, ulcer ect are better treated with herbal plants and therapy is easy with fewer side effects. The lipid lowering agents are also obtains from herbal plants and used in the the patients. The obesity is also controlled by various herbal formulations in the markets. The collection of plant from hilly stations and then dried them is the major problem in this field. The collected leaves, roots, barks, fruits, seeds are properly dried so that the active constituents should not be destroyed or inactivated during their drying process. Then the material is pulverized under grinding mill or grinder with proper impact and screening of the particles.

For the analysis of herbals, HPTLC offers a number of advantages. The technique is especially suitable for comparison of samples based on fingerprints. Apart from conveniently performing quantitative determinations based on scanning densitometry or video technology has become a cost and time-effective alternative to HPLC.

For an analytical perspective, herbs and herbal preparations are particularly difficult to standardize. Pharmacological activity is established in many instances but there are also many situations in which claimed activity has not yet been scientifically proven. If a plant based product is introduced to the market, it becomes necessary to define its botanical authentication of the herb based on its phenotype. Possibly phenotype and some understanding about its natural variability resulting from its geographic location, developmental stage, climate and so on. Next, the chemical and biochemical composition of the material should be investigated. 
By definition, standardized extracts are extracts of herbs with predefined active constituents and having specified chemical, physical, biological and organoleptic characteristics. A standardized herbal extract involves predetermining one or a number of biochemical constituents as either active or marker compounds. The result involves two very distinct types of extracts.

Sida Cordifolia extract is a semisolid/dry extract of the Sida cordifolia plant root, containing $0.8 \%$ to $1.2 \%$ of the alkaloid ephedrine and $6-8 \%$ of total alkaloids. It is considered to be one of the most valuable drugs in Ayurveda. It is used by Ayurveda physicians as an antipyretic in febrile and infectious diseases, and also as an aphrodisiac.
Sida Cordifolia is also useful in the treatment of chronic broncho-pulmonary conditions characterized by bronchospasm and cough.

The importance of Sida Cordifolia becomes apparent as it contains ephedrine alkaloids common to the Ephedra plant (also known by its Chinese name: Ma-Huang). Sida Cordifolia contains lesser quantities of alkaloids than Ma-Huang, and therefore is regarded as a weaker stimulant on cardiovascular and central nervous systems. Furthermore, Sida Cordifolia contains other bronchodialating principles which Ma-Huang does not have in particular vasicinone, vasicine, and vasicinol.

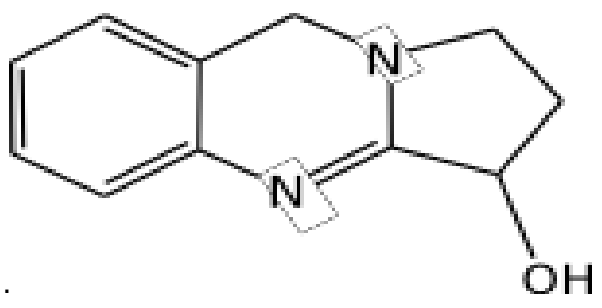

VASICINE ALKALOID

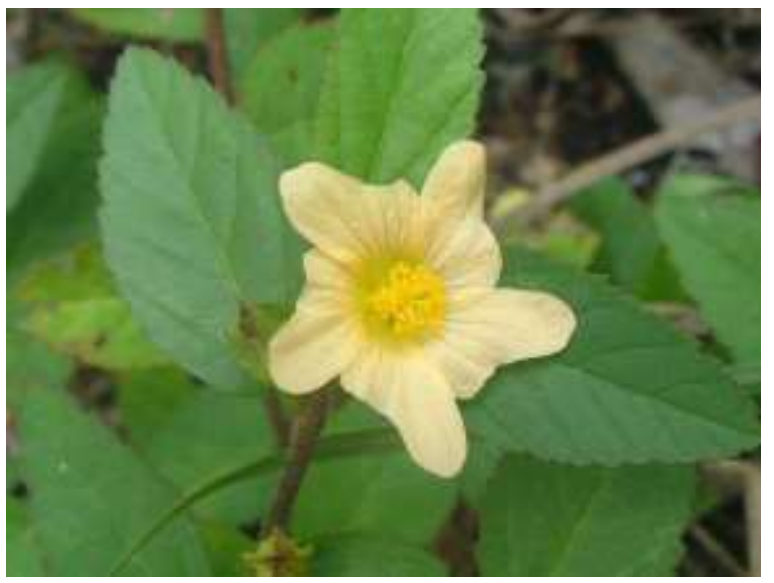

SIDA ACUTA

\section{Anatomical description:}

Shrubby, much branched, branches slender, terete, minutely stellately hairy, leaves $2.5-6.6 \mathrm{~cm}$ long, lanceolate, with rounded base sharply serrate, glabrous on both side, petioles $0.6 \mathrm{~cm}$ long, lobes triangular, acute. Corolla nearly twice as long as the calyx, yellow. Fruit $5.6 \mathrm{~mm}$ diameter, carpels 5-9, puberlous, not pubescent, strongly reticulated toothed on the dorsal margins. Seeds smooth, black.
Uses:

Root sour and sweet, removes 'tridosha' digestive and diuretic, useful in fever, burning of the body and urinary discharges. The root is regarded as cooling, astringent, tonic and useful nervous and urinary diseases and also in disorders of the blood and bile.

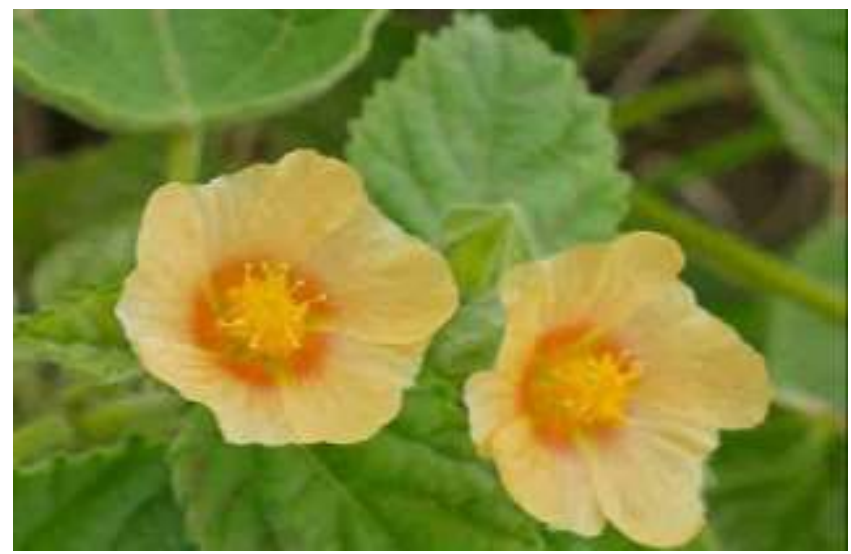

SIDA CARDIFOLIA 


\section{MATERIALS \& METHODS:}

\section{(1) Plant material and Chemicals:}

Roots and Leaves of Sida species were collected directly from road side to different part of India. Materials were air dried at room temperature and powdered mechanically. The powdered of roots and leaves were used as the plant material for all analysis. Chemicals, instruments, glassware used in the process were listed in table 1.1, 1.2, 1.3 and 1.4

\section{(2) Isolation and Extraction:}

\section{Objective of Research Work}

1. To collect plant material from different geographical locations.

2. To identify and authenticate of plants species.

3. To carry out pharmacognostical study of Sida species (botanical description of plant, anatomy of Sida species, powder microscopy)

4. To extract the plant ariel part with different solvents

5. To isolate the active chemical constituents and test pharmacological applications

\section{Methods for Preparing Extracts of Sida Species}

\section{Sida cordifolia root extract}

1) Well identified roots were dried and crushed to a coarse powder.

2) This coarse powder (150 g) were extracted by $700 \mathrm{ml}$ ,80\% methanol at 60-65 temperature for $4-5 \mathrm{hrs}$

3) Three successive extractions were done.

4) After every extraction vacuum filtration was done.

5) All washings were combined and reduced under vacuum at temp $60-65^{\circ} \mathrm{c}$ till all methanol removed, $300 \mathrm{ml}$ aqueous mass was obtained.

6) To this, dil H2So4 was added drop wise till $\mathrm{pH}$ made 34.This aqueous mass was washed with $3 \times 300 \mathrm{ml}$ Hexane to remove the fats and waxy materials.

7) This aqueous mass was reduced under vacuum at temp $60-65^{\circ} \mathrm{c}$ to obtained a thick paste.

8) This paste was dried in vacuum drier at temp $40-45^{\circ} \mathrm{c}$.

9) Total alkaloidal content was estimated

10) Weight of extract was found $6.46 \mathrm{gm}$.

\subsubsection{Sida rhombifolia root extract}

1) Well identified roots were dried and crushed to a coarse powder.

2) This coarse powder (100 g) were extracted by $600 \mathrm{ml}$ , $80 \%$ methanol at $60-65^{\circ}$ temperature for $3-4 \mathrm{hrs}$

3) Three successive extractions were done.

4) After every extraction vacuum filtration was done.

5) All washings were combined and reduced under vacuum at temp $60-65^{\circ} \mathrm{c}$ till all methanol removed, $300 \mathrm{ml}$ aqueous mass was obtained.

6) To this, dil H2So4 was added drop wise till $\mathrm{pH}$ made 34.This aqueous mass was washed with $3 \times 300 \mathrm{ml}$ Hexane to remove the fats and waxy materials.

7) This aqueous mass was reduced under vacuum at temp $60-65^{\circ} \mathrm{c}$ to obtain a thick paste.
8) This paste was dried in vacuum drier at temp $40-45^{\circ} \mathrm{c}$.

9) Total alkaloidal content was estimated

10)Weights of extract were found $4.265 \mathrm{gm}$.

\subsubsection{Sida cordifolia aerial part Extract:-}

1. Aerial parts were dried under shadow and milled into coarse powder.

2. $450 \mathrm{gm}$ of coarse powder were successively extracted thrice with 2 liters of $80 \%$ methanol at $60-65^{\circ} \mathrm{c}$ temperature for 3-4 hrs

3. Vacuum filtration was done after each extraction.

4. All washings were combined; this extracted liquid was transferred to distillation assembly provided with vacuum and agitation system.

5. This extracted liquid was reduced under vacuum at 50$55^{\circ} \mathrm{c}$ up to $600 \mathrm{ml}$. (all methanol removed ,checked by hydrometer)

6. This aqueous mass was cooled to $20-22^{\circ} \mathrm{C}$ and $15 \mathrm{ml}$ dil H2So4 was added till pH 3-4 and kept for overnight .Some oily, waxy and green matter was settle down.

7. This aqueous mass was filtered, and oily marc was agained washed with N/10 H2So4 (30 ml) thrice.

8. All acid washings were combined and filtered.

9. All filtrates (acid washings and filtered aqueous mass) were combined $(700 \mathrm{ml})$.

10. To this equal volume of hexane $(700 \mathrm{ml})$ was added, this was warmed at $45-50^{\circ} \mathrm{c}$ and stirred for 20-30 minutes and layers were separated in separating flask. Like this 2-3 successive washings by hexane were done.

11. The aqueous extract was taken in a separating funnel and partitioned with $3 \times 500 \mathrm{ml}$ of chloroform to remove the chlorophyll, fats and other pigments.

12. Aqueous layer was taken and reduced under vacuum 50 $55^{\circ}$ to afford a thick paste $(32 \mathrm{~g})$.

13. This paste was dissolved in $500 \mathrm{ml}$ solvent mixture (Methanol: Ethylene dichloride (65: 35)).

14. To this, $100 \mathrm{ml}$ of water was added. The contents were stirred for $10 \mathrm{~min}$ and allowed to stand till both the phases were separated (about 3-4 hrs).

15. The lower layer was constituted of EDC soluble components and was washed with $10 \mathrm{ml}$ of water to remove the residual methanol.

16. The EDC was distilled off in a separate distillation vessel. On complete removal of solvent, a paste was obtained in yield $2.3 \%$ (10.35gm). Alkaloidal content was calculated and was found $10.56 \%$.

17. The aqueous methanolic layer was combined with water washing and solvent was recovered and a thick paste in a yield of $4.1 \%$. (21.6 gm) was obtained.

18. This paste (7gm) was combined with EDC paste to get final product. The combined paste was dried in a vacuum drier and the yield was $15.35 \mathrm{gm}$.

19. Alkaloidal content was calculated and was found $7.14 \%$.

20. This dried paste packed in double sealed moisture proof polyethylene bags. 


\section{Preparation of Sida Cordifolia Extract (6- 8 \% Alkaloid)}

Dried aerial parts

\section{Coarse powder $450 \mathrm{gm}$}

three successive extraction with 2 lit solvent mixture $(80$ parts methanol +20 parts water , $1600 \mathrm{ml}$ methanol $+400 \mathrm{ml}$ methanol at $60-65^{\circ}-\mathrm{C}$. temp $3-4 \mathrm{hrs}$

Filtered combined and evaporated in vacuum at $55^{\circ} \mathrm{C}$ to $600 \mathrm{ml}$ cooled to $20^{\circ} \mathrm{C}, 15 \mathrm{ml}$ dil $\mathrm{H} 2 \mathrm{So} 4$ was added to make $\mathrm{pH} 3-4$, kept for overnight, oily, waxy and green matters settled down

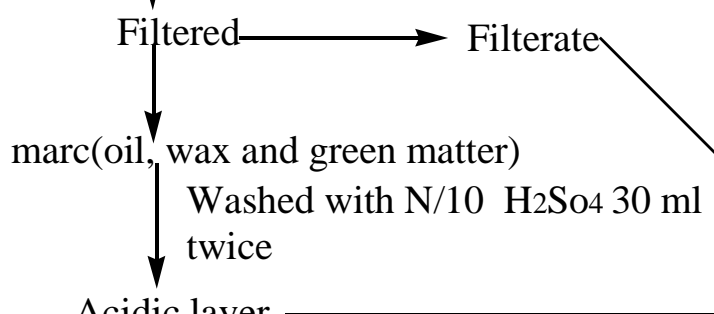

Acidic layer $\longrightarrow$ combinedAqueous layer $(700 \mathrm{ml})$

$700 \mathrm{ml}$ Hexane added,

stirred for 20-30 minutes at 50 $\mathrm{C}, 2-3$ times

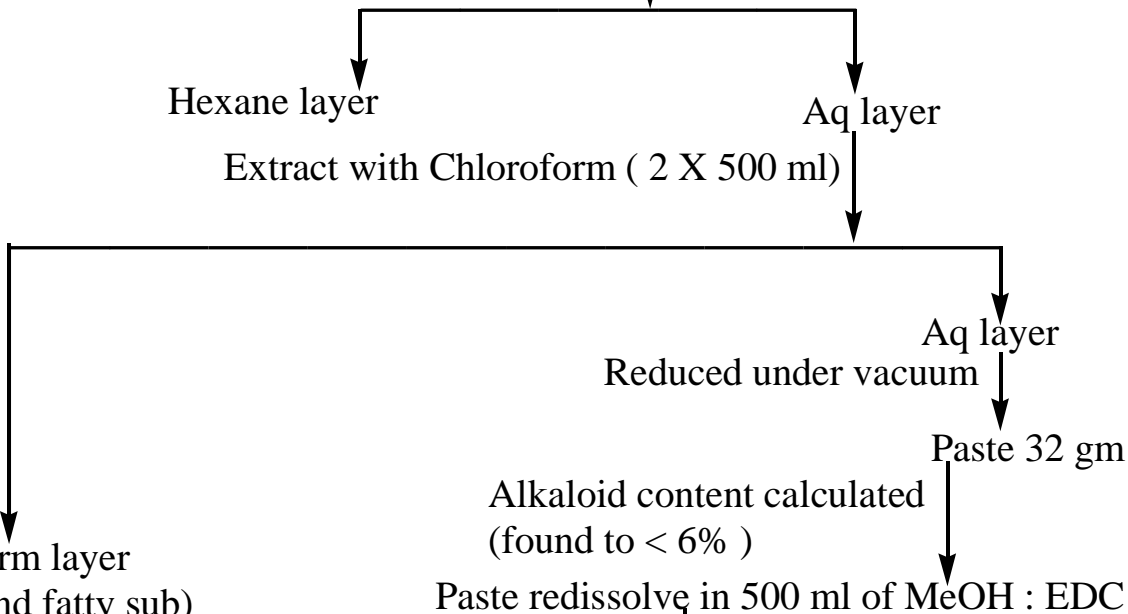

(Chlorophyl and fatty sub)

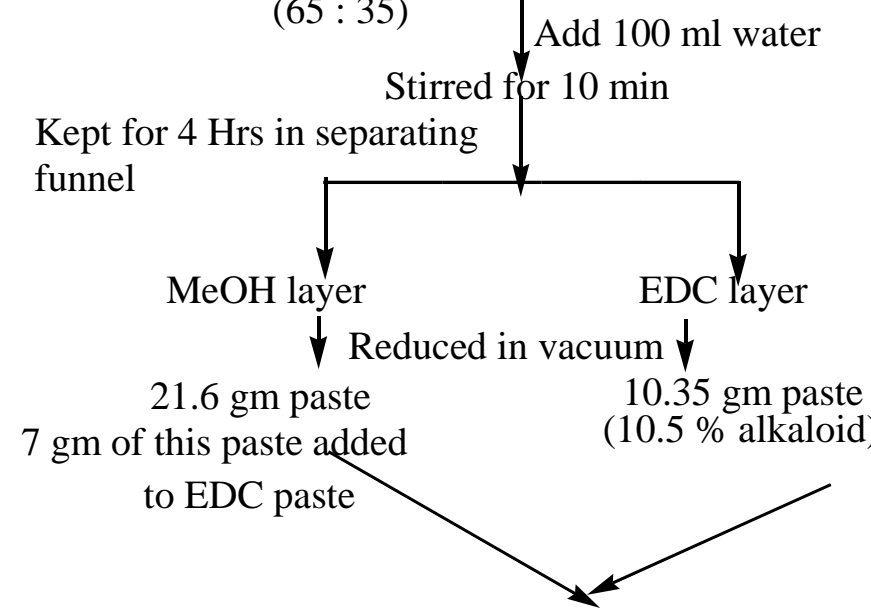

$15.35 \mathrm{gm}$ paste $(7.1 \%$ alkaloid $)$ 


\section{Preparation of Sida Acuta Extract (6- 8 \% Alkaloid)}

Dried aerial parts

Coarse powder $300 \mathrm{gm}$

three successive extraction with 1.5 lit solvent mixture $(80$ parts methanol + 20 parts water, $1200 \mathrm{ml}$ methanol $+300 \mathrm{ml}$ methanol at $60-65^{\circ}-\mathrm{c}$. temp, $3-4$ hrs

Filtered combined and evaporated in vacuum at $55 \mathrm{C}$ to $500 \mathrm{ml}$
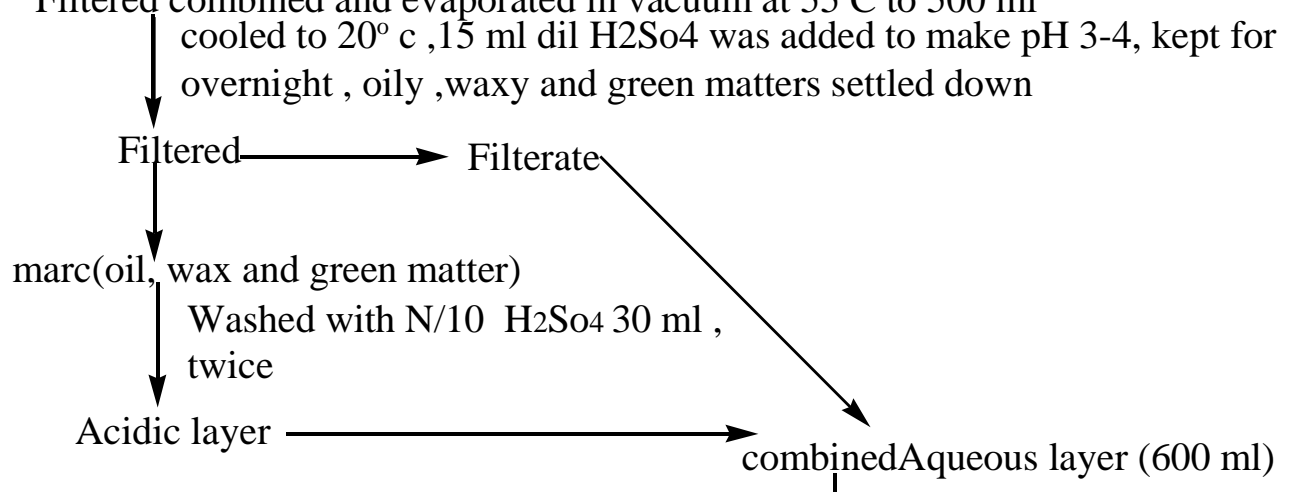

$600 \mathrm{ml}$ Hexane added,

stirred for 20-30 minutes at $50^{\circ} \mathrm{c}, 2-3$ times

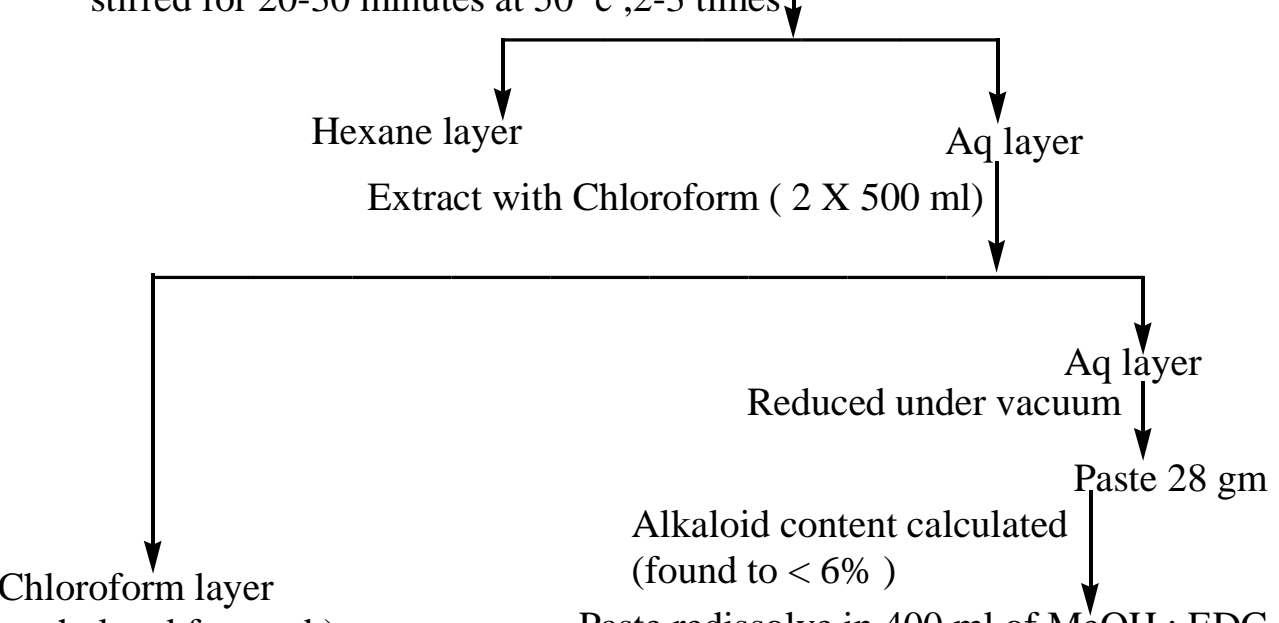

(Chlorophyl and fatty sub)

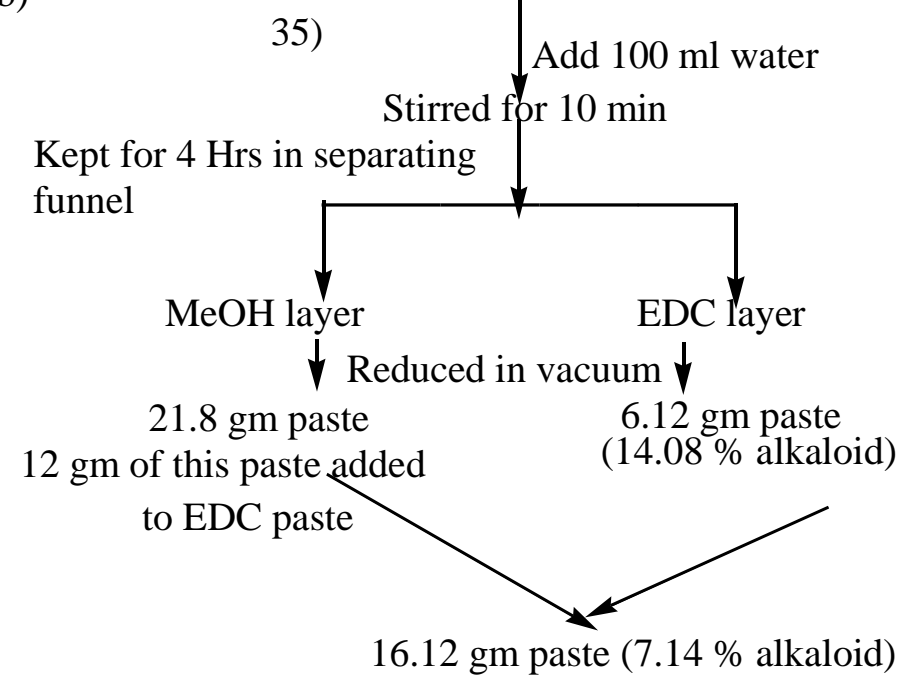




\section{RESULTS AND DISCUSSION:}

\begin{tabular}{|l|l|l|l|l|l|}
\hline S.No & Histological character & Sida cordifolia & Sida acuta & Sida rhombifolia & Sida spinosa \\
\hline 1 & Cutucle & Present & Absent & Present & Present \\
\hline 2 & Upper epidermis & $\begin{array}{l}\text { Signle layered round } \\
\text { shaped with unicellular } \\
\text { trichomes. }\end{array}$ & $\begin{array}{l}\text { Bilayered } \\
\text { rectangular shaped }\end{array}$ & $\begin{array}{l}\text { Signle layered } \\
\text { round shaped }\end{array}$ & $\begin{array}{l}\text { Signle layered } \\
\text { rectangular shaped } \\
\text { with unicellular } \\
\text { trichomes. }\end{array}$ \\
\hline 3 & Collenchyma & Present & Absent & Absent & Absent \\
\hline 4 & Vascular bundle & $\begin{array}{l}\text { Crescent shaped } \\
\text { endarch type }\end{array}$ & $\begin{array}{l}\text { Arch shaped thick } \\
\text { deposition over } \\
\text { vascular bundle }\end{array}$ & Arch shaped & $\begin{array}{l}\text { Radial vascular } \\
\text { bundle }\end{array}$ \\
\hline 5 & Endodermis & $\begin{array}{l}\text { Oval shaped cells with } \\
\text { thick deposition. }\end{array}$ & $\begin{array}{l}\text { Deposition over } \\
\text { endodermis }\end{array}$ & $\begin{array}{l}\text { Arch shaped cells } \\
\text { present beneath the } \\
\text { xylem vessels }\end{array}$ & $\begin{array}{l}\text { Oval shaped cells } \\
\text { present beneath } \\
\text { the xylem vessels }\end{array}$ \\
\hline 6 & Parenchyma & $\begin{array}{l}\text { Parenchyma cells } \\
\text { surrounding the } \\
\text { vascular bundle }\end{array}$ & $\begin{array}{l}\text { 3-4 layers of } \\
\text { parenchyma } \\
\text { surrounding the } \\
\text { vascular bundle }\end{array}$ & $\begin{array}{l}\text { 2-3 layers } \\
\text { surrounding the } \\
\text { endodermis }\end{array}$ & $\begin{array}{l}3 \text { layers of rounded } \\
\text { shaped cells } \\
\text { beneath the } \\
\text { endodermis }\end{array}$ \\
\hline 7 & Lower epidermis & $\begin{array}{l}\text { Signle layerd round } \\
\text { shaped with unicellular } \\
\text { trichomes. }\end{array}$ & $\begin{array}{l}\text { Round shaped cells } \\
\text { with single layered }\end{array}$ & $\begin{array}{l}\text { Single layered, } \\
\text { round shaped. }\end{array}$ & $\begin{array}{l}\text { Single layered, } \\
\text { round shaped with } \\
\text { trichomes }\end{array}$ \\
\hline
\end{tabular}

\subsubsection{Sida cordifolia root extract}

A band (Rf 0.21) corresponding to ephedrine and another band ( $\mathrm{Rf} 0.28$ ) corresponding to vasicine are visible in both reference and solution tracks. Five other bands appear at Rf values of $0.41,0.61,0.69,0.73 \& 0.83$ at $254 \mathrm{~nm}$.

Four bands appear at $\mathrm{Rf}$ values of $0.42,0.69,0.73 \& 0.80$ at $366 \mathrm{~nm}$.

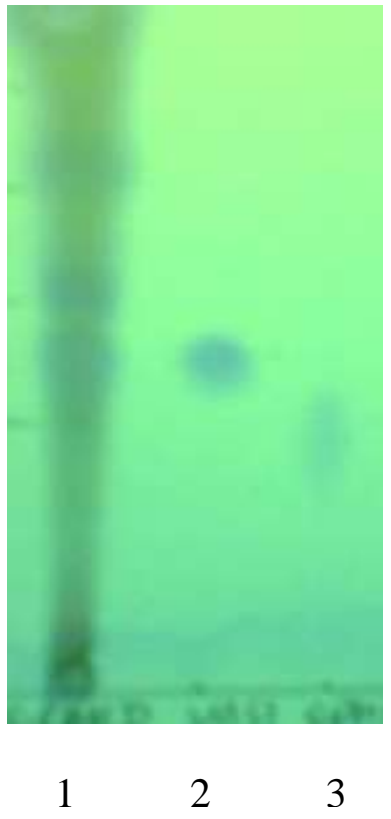

A

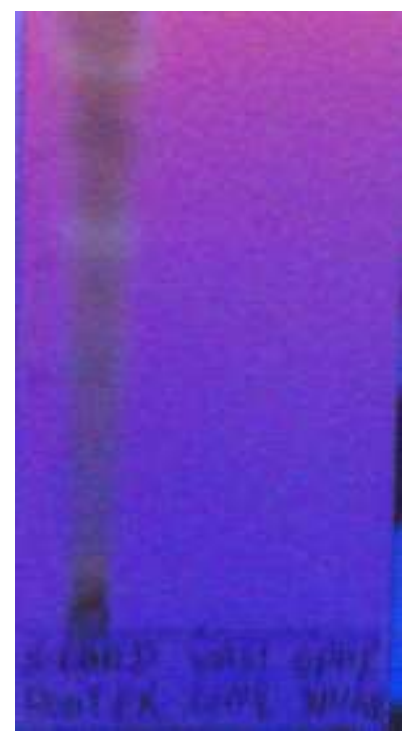

1 2 B
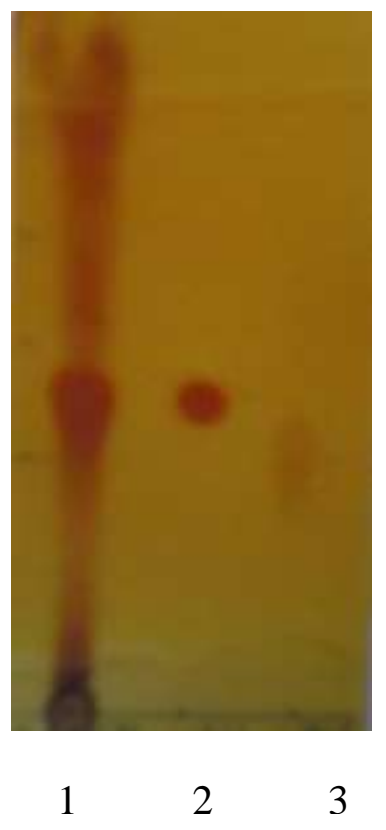

C

Figure 1: TLC profile of Sida cordifolia root extract

A. under UV light at $254 \mathrm{~nm} \quad$ B under UV lightat $366 \mathrm{~nm}$. C under visible light after spraying with Dragondroff reagent

1. Test solution of Sida cordifolia root extract

2. Vasicine standard

3 Ephedrine standard 


\title{
Visualization of spots after spraying with ninhydrine reagent under visible light
}

This confirms the ephedrine violet red spots are visible at Rf 0.19 in both test and reference after spraying with ninhydrine reagent and heating the plate for $5-7$ mints.

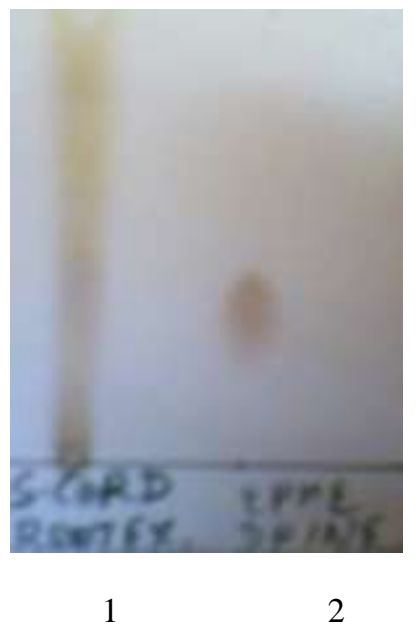

Figure 2: TLC plate, spraying with ninhydrine reagent

\subsubsection{Sida acuta aerial part extract}

A band (Rf 0.19) corresponding to ephedrine is visible in reference track and another band (Rf 0.25 ) corresponding to vasicine is visible in both reference and solution tracks. Five other bands appear at Rf values of 0.12. 0.23, 0.40, 0.68 and
0.73 at $254 \mathrm{~nm}$. Six bands appear at Rf values of $0.06,0.13$, $0.39,0.65,0.73 \& 0.82$ at $366 \mathrm{~nm}$

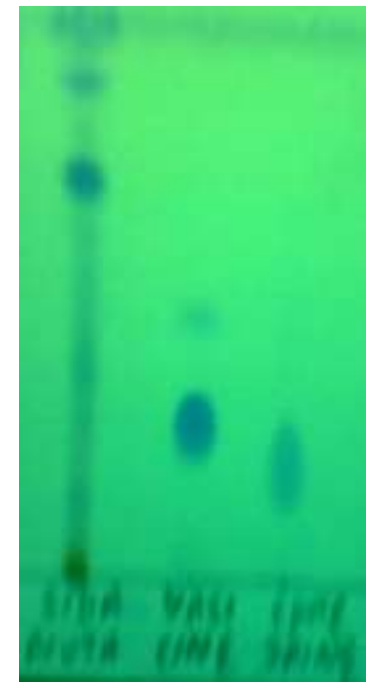

1

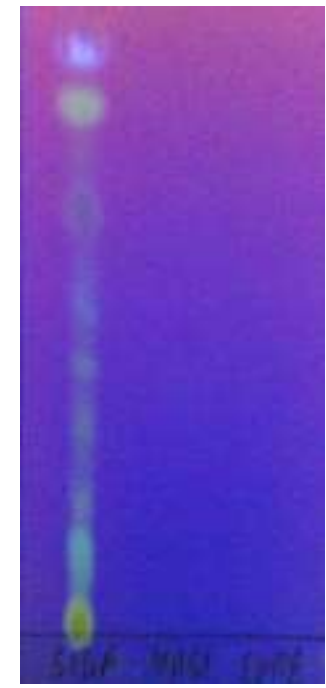

123

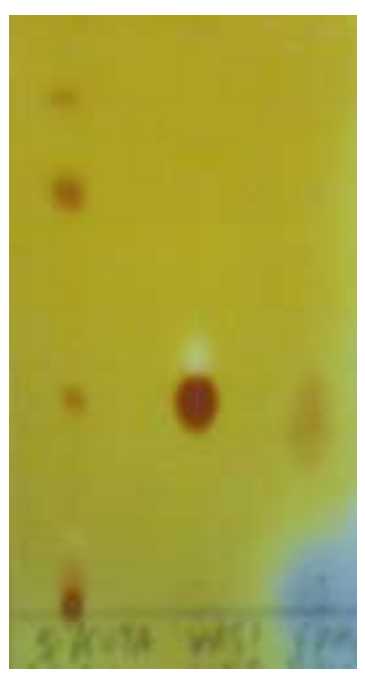

$1 \quad 2 \quad 3$

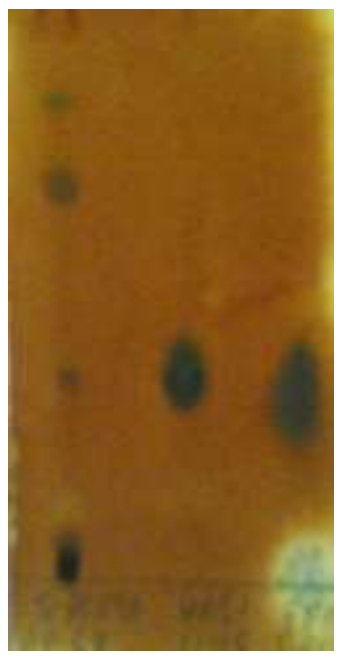

$\begin{array}{lll}1 & 2 & 3\end{array}$

A

B

C

D

Figure 3: TLC profile of Sida acuta aerial part extract

\footnotetext{
A. under UV light at $254 \mathrm{~nm}$

B under UV lightat $366 \mathrm{~nm}$.

C under visible light after spraying with Dragondroff reagent

D under visible light after spraying with DRG followed by Sodium nitrite
}

\author{
1. Test solution of Sida acuta aerial part extract \\ 2. Vasicine standard \\ 3 Ephedrine standard
}




\section{Compiled HPTLC Chromatograms of all Extracts}

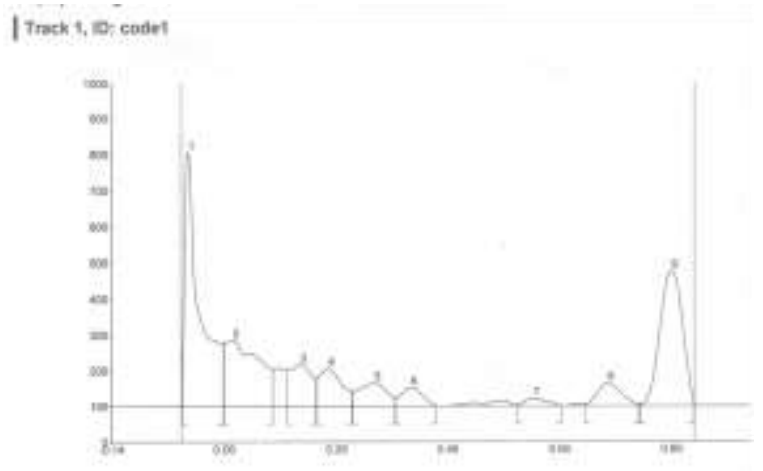

$* 3,10:$ codes

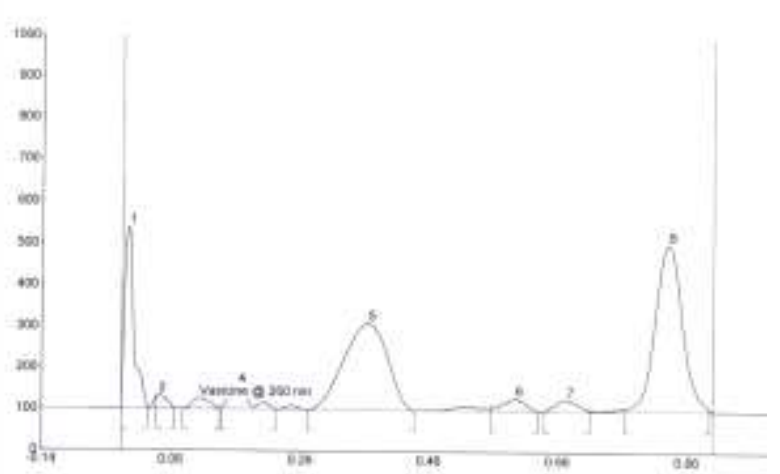

Figure 4: 1.Chromatogram Sida spinosa extract

3. Chromatogram Sida rhombifolia aerial part

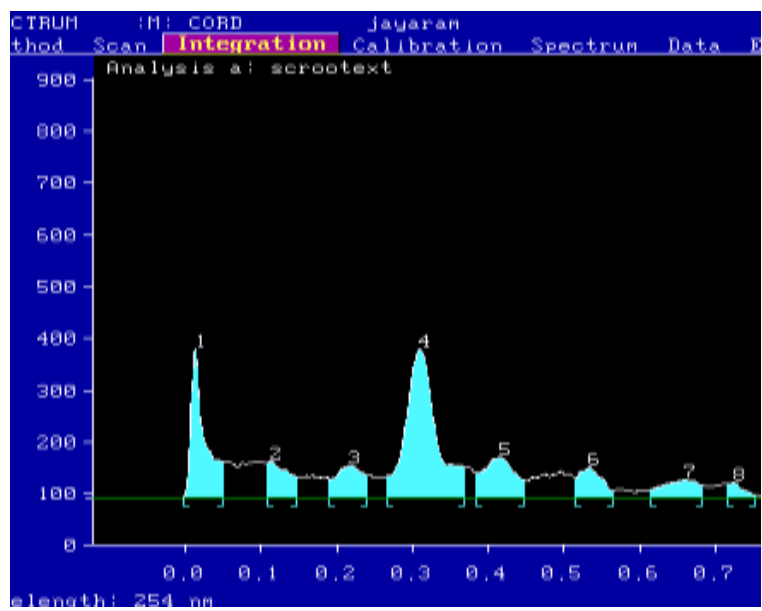

Figure 5: HPTLC Chromatogram Sida cordifolia root extract

\section{CONCLUSION}

From all these studies we can conclude that Sida cordifolia aerial part extract can be safely used as substitute of Sida cordifolia root extract (because of all parameters are matching)

Sida rhombifolia plant is being commercially cultivated, so its root extract can also be used as substitute of Sida cordifolia root extract. With minor adjustment, Sida rhombifolia aerial part extract can also be used as substitute of Sida cordifolia root extract.
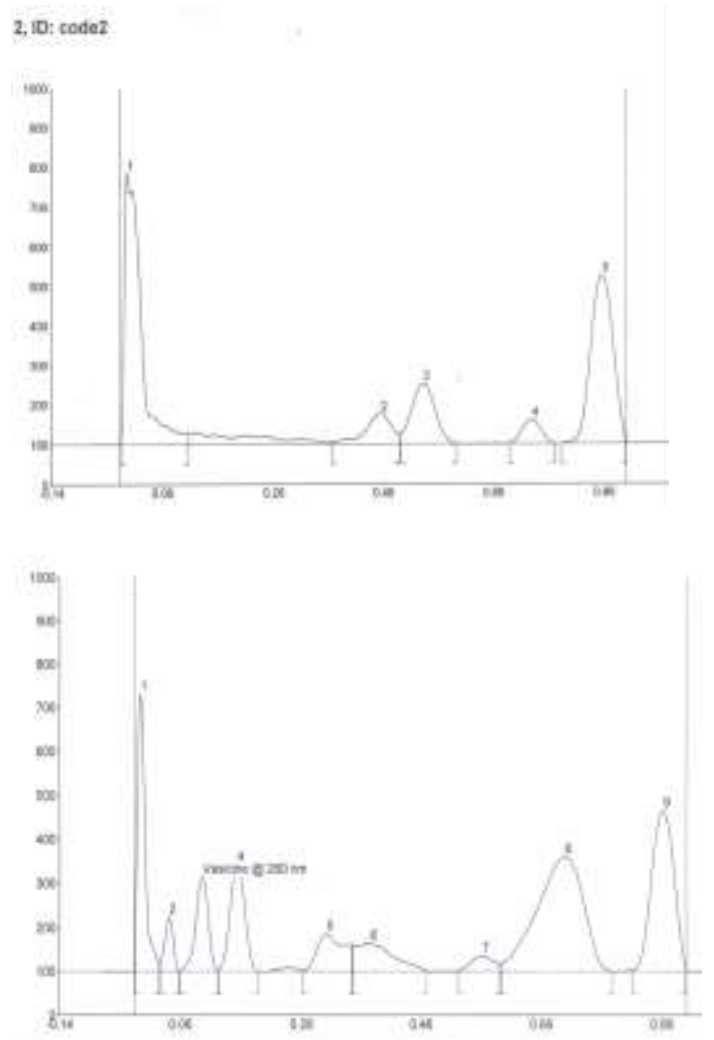

2 Chromatogram Sida acuta extract

4 Chromatogram Sida rhombifolia extract root extract

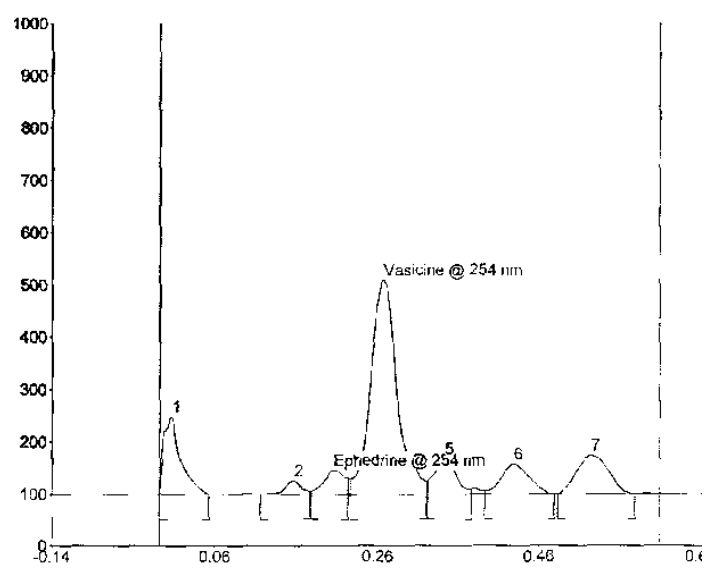

Figure 6: HPTLC Chromatogram Sida cordifolia aerial part extract
It can be suggested that since Sida cordifolia is perennial plant and if its aerial parts only are collected for preparation of extract, the Sida cordifolia can be saved from getting extinct. The HPTLC fingerprinting of the two have been found to be similar.

Further commercial cultivation method for this plant should be developed as it is difficult to propagate the plant from seeds. The micro propagation may be tried. For commercial and industrial purpose aerial parts of Sida cordifolia can be recommended for following reasons.

Milling of root is difficult 
$>$ From a single plant we are getting $50 \mathrm{gm}$ of aerial powder but only 3-4 gram of root powder.

$>$ Extraction of aerial part is easy and it takes less time as compared from root extraction.

Also by mixing extracts from aerial parts of Sida spinosa, Sida acuta \& Sida rhombifolia and Sida rhombifolia root extract in appropriate quantity to match almost all parameters to Sida cordifolia extracts, the resultant extract can be used as a substitute of Sida cordifolia root extract.

1. Histology of stem of Sida species.

From histological study of stem it has been found that there is no marked difference in gross anatomy among the Sida acuta, Sida spinosa and Sida rhombifolia. However, there is a marked difference in histological character between Sida cordifolia and Sida acuta. Details have been tabulated in table 12. Trichomes are present only in Sida cordifolia.

\section{Histology of leaf of Sida species}

There is marked difference between 4 Sida species as far as the histology of leaf is concerned. The differences in histological characters between these Sida species have been tabulated in table 11.

\section{Microscopical evaluation of crude powder.}

The diagnostical charecters of Sida species are summarized in table 13. In powder microscopy, presence of ' $U$ ' shape stone cells in leaf of Sida rombifolia is diagnostic character for its correct identification from other 3 Sida species.

Anisocytic stomata are present in Sida cordifolia and Sida spinosa. But in Sida rombifolia and Sida acuta paracytic stomata is present.

\section{Powder microscopy of stem of Sida species}

There is no significant difference. However, unicellular star shaped trichomes are present in Sida cordifolia only and absent in remaining 3 species.

5 . The ash value of aerial parts of the Sida species have been tabulated in table 16 and the major constituent (metals) have been tabulated in table 17. The ash value and metal contents values of Sida cordifolia are higher than rest 3 species. Heavy metals were determined in extracts prepared from Sida species. Arsenic, Nickel and Lead were below the permissible limits.

6 The extractive values of aerial parts of the Sida species have been tabulated in table 15

$>$ From the table it has been found that extractive value of Sida spinosa is higher than rest of species with respect to solvent water.

$>$ With methanol \% of extractive value of Sida cordifolia is found to be more than other species and the \% of extractive value of Sida rhombifolia is less than other species.

$>$ With ethanol \% of extractive value of Sida cordifolia is found to be more than other species. This shows that ethanol soluble contents are more in Sida cordifolia than other species.

$>$ With chloroform \% of extractive value of Sida acuta is much higher than other species.

$>$ With benzene there is no significant difference in the extractive values of Sida species.

$>$ With pet. ether \% of extractive value of Sida rhombifolia is more than other species.
6. TLC examination of extracts of Sida species revealed that Vasicine (Rf $0.26 \pm 0.01$ ) is present in all extracts. Ephedrine (Rf $0.20 \pm 0.01$ ) is present in Sida cordifolia root extract, Sida cordifolia aerial part extract, Sida rhombifolia root extract and Sida rhombifolia aerial part extract but absent in aerial part extract of Sida acuta and Sida spinosa.

Differences at $254 \mathrm{~nm}$ and $366 \mathrm{~nm}$ have been tabulated in table 18.

Sida cordifolia aerial part extract shows bright flouresecnce at $\mathrm{Rf}$ 0.73. Sida acuta extract shows broad zone of flourescence at Rf 0.12 at $366 \mathrm{~nm}$ which is absent in all extracts. Sida spinosa aerial part extract shows major spot at Rf 0.39 at $254 \mathrm{~nm}$. Sida acuta aerial part extract shows major spot at Rf 0.68 at $254 \mathrm{~nm}$. These compounds are not identified. Sida rhombifolia root extract and Sida rhombifolia aerial part extract show major spot at Rf 0.58 at $254 \mathrm{~nm}$.

In TLC identity of extracts if plate is viewed under UV at $366 \mathrm{~nm}$, bright fluorescence spots in region, Rf 0.11-0.2, 0.60.7 and number of other fluorescence spots at different $\mathrm{Rf}$ value are present in Sida rhombifolia root extract.

After spraying the TLC plates with dragendroff reagent Sida Cordifolia root extract, Sida cordifolia aerial part extract, Sida rhombifolia root extract and Sida rhombifolia aerial part extract shows the same pattern. It means almost similar alkaloids are present in Sida cordifolia root extract and its aerial part extract and in the aerial part extracts of other species.

\section{Estimation of alkaloidal content}

Alkaloidal content is 6-8\% in all extracts.

\section{HPTLC analysis}

Vasicine $(1-1.3 \%)$ and ephedrine (0.6-0.8\%) are present in Sida cordifolia root extract, Sida cordifolia aerial part extract and Sida rhombifolia root extract.

HPTLC finger printing of Sida cordifolia root and its aerial part extract is matching. It means that the extracts prepared from root and aerial parts of Sida cordifolia are similar in nature.

HPTLC finger printing of Sida rhombifolia root extract, 5 peaks are matching with HPTLC finger printing of Sida cordifolia root extract. This means that two extracts are similar in nature.

HPTLC finger printing of Sida rhombifolia aerial part extract, 3 peaks particularly Ephedrine and Vasicine are matching with HPTLC finger printing of Sida cordifolia root extract. Thus indicating that extracts may have similar properties.

\section{Qualitative analysis}

Parameters like $\mathrm{pH}$, solubility, organoleptic characteristics, $\%$ of ash, heavy metal content and microbiological analysis have been tabulated in table20. These parameters are almost similar in all Sida extracts.

\section{REFERENCES:}

1. Bhutani. K. K, "Herbal Medicine - An Enigma and Challenge to Science and Directions for new Initiatives". Indian J of Natural Product, 2003; 19(1): 3-10.

2. Edwin. E., et.al., "The Eastern Pharmacist", 2005; IV:38-42.

3. Mukherjee, P and Smanta, M.K., Herbal drug development - A modern approach, IJPE, 2002; 33(4).

4. Herbal drug - The manufacturing standardization, characterization - The Eastern Pharmacist, 2000; 33(4):202. 
5. Indian Herbal Pharmacopoeia, published by RRL (Jammu Tawi) and IDMA (Mumbai) India, 1998; 67:165.

6. Bhutani. K. K., finger printing of ayurvedic drugs, Eastern pharmacist, 2000; 21-26.

7. Sethi, P.D., HPTLC Quantitative Analysis of Pharmaceutical Formulation, CBS Publishers and Distributors. 1st Edition New Delhi, India, 1996; 4:57.

8. Awdhesh Oraon., Pharmacognostical investigation on Sida species of chotanagpur, M.Pharma Thesis, B.I.T, Mesra, Ranchi, 2001; 18-19.

9. Oudhia. P., society for parthenium management, www.celestineindia.com.

10. Indian Herbal Pharmacopoeia Revised New edition, 2002; 384392.

11. The Ayurvedic Pharmacopoeia of India, part-1, vol. 3. $1^{\text {st }}$ ed. New Delhi: Government of India , Ministry of Health \& Family welfare,Department of Indian system of medicine \& Homeopathy; 2001; 110-111.

12. Chunekar K.C. Bhavaprabashnighantu Pandey G.S editor, Chaukhambha Bharti Academy; Varanasi. P. 368. 1969

13. Sharma P.V. Dravyguna - Vijnana, Vol-2, First Edition. Varanasi; Chaukhambha Bharti Academy; P. 734-737. 1969
14. Rajpal.V., Standardization of Botanicals, Testing \& extraction methods of Medicinal herbs, 2005; 2:307-313.

15. The wealth of India- Raw materials, Vol-7. Publications \& Information Directorate, Council of Scientific and Induatrial Resaerch New Delhi: -; P. 324-325. 1992

16. DeepakM. Standardization of Some herbal drugs using chromatographic Techniques. Ph.D Thesis, B.I.T, Mesra, Ranchi.. P. 68-76. 1999

17. Sivarajan.V.V., and Balachandran.I., Ayurvedic Drugs and their Plant sources, Oxford and IBH Publishing Co.Pvt Ltd, New Delhi, $71,1994$.

18. Kapoor. L.D., Handbook of Ayurvedic Medicinal Plants, CRC press, Florida, P. 303, 1990.

19. Ghosh. S., and Dutta., J. Indian. Chem. Soc., 1930; 7:P 825.

20. Ghosal.S., Ballav.R., Chauhan .P.S., and Mehta.P, "Alkaloids of Sida cardifolia" J. Phytochemistry; 1975; 14:830-832. https://doi.org/10.1016/0031-9422(75)83057-3

21. The wealth of India- Raw materials, Vol-7. Publications \& Information Directorate, Council of Scientific and Induatrial Resaerch New Delhi: -; P. 324, 1992 